\title{
MULTIMEDIA SYSTEM TO SUPPORT \\ THE LIPOPROTEINS METABOLISM TEACHING-LEARNING PROCESS
}

\author{
Luciana Vieira Castilho ${ }^{2}$, Maria Cecilia Kohler ${ }^{3}$, Maria Lúcia Wambier Klüppel', \\ Wagner Rodrigo Weinert ${ }^{2}$, Patrícia Maria Stuelp-Campelo $^{1}$ \\ ${ }^{1}$ Curso de Farmácia, PUC-PR, Curitiba-PR; ${ }^{2}$ Laboratório de Bioinformática e \\ Informática Médica, UTFPR, Curitiba-PR; ${ }^{2}$ Laboratório de Neurobiologia e \\ Hematologia Celular e Molecular, UFSC, Florianópolis-SC.
}

The present work considers the use of informatics as a support to the learning of the metabolism of lipoproteins. They are important to transport lipids through blood, which are insoluble in water and needs to be carried to the tissues to keep the homeostasis. Its learning is considered complex because contains many simultaneous biochemical processes. There is a great variety of information about this process to be learnt, especially if will have considered the number of molecules and events involved in the process. The complexity and importance of this content motivated us to develop LipoLS. It is a multimedia system that approaches the lipoprotein metabolism learning. This system integrates animations, texts, self-evaluation questionnaires and case studies, to motivate the collaborative learning. The methodology used for the software project was the data flow diagram and for the development of the system had been used the animation software Macromedia Flash MX 2004 and implemented with the software Macromedia Director MX 2004. The software LipoLS is an alternative resource that is able to facilitate the teaching-learning process. It takes advantage on student's interest on informatics and changes the ways of teaching and learning Biochemistry.

Keywords: Lipoproteins, Education, Informatics. 